\title{
Performed Substance Administration Active Ingredient Dose Description
}

National Cancer Institute

\section{Source}

National Cancer Institute. Performed Substance Administration Active Ingredient Dose

Description. NCI Thesaurus. Code C95374.

The textual representation of active ingredients in the dosing amounts or a range of dosing information used in a substance administration. (BRIDG) 